\title{
Language Policy and Power in Out-of-Classroom EFL Contexts: The Case of English Departments in Saudi Arabian Higher Education Institutions
}

\author{
Mohammad Almoaily ${ }^{1}$ \\ ${ }^{1}$ College of Arts, King Saud University, Saudi Arabia \\ Correspondence: Mohammad Almoaily, College of Arts, King Saud University, P.O. Box 2456, Riyadh 11451, \\ Kingdom of Saudi Arabia. E-mail: malmoaily@ksu.edu.sa
}

Received: October 23, 2018 Accepted: November 15, 2018 Online Published: February 24, 2019

doi:10.5539/ijel.v9n2p136 URL: https://doi.org/10.5539/ijel.v9n2p136

\begin{abstract}
Most of the research on language policies in educational institutions has hitherto focused on the creation, interpretation, or appropriation of language policies that govern language use in the classroom. Language policies, however, can be instantiated or implemented in out-of-classroom settings. Hence, the current study examines the impact of language policies, in terms of both beliefs and practices, as mechanisms of power in communication between staff members in official meetings taking place at higher education institutions in Saudi Arabia. An online survey taken by 208 members, in addition to semi-structured interviews with eight department chairpersons, revealed that the implementation of monolingual English language policies can minimize the proportion of engagement of staff members, who are less competent in English, in department council meetings, committee meetings, and other official meetings. The data also suggested that the majority of participants in the study believe that multilingual language policies (allowing the use of both Arabic and English) should be avoided in order to not exclude non-Arabic speaking staff members from participation in official dialogue. The study concludes with implications for language policy creation and implementation for out-of-classroom English use in EFL educational institutions.
\end{abstract}

Keywords: EFL, language beliefs, language choice, language policy, language use

\section{Introduction}

Monolingual educational policies have long been accused of marginalizing students of other linguistic backgrounds (see Skutnabb-Kangas, 2000; Nicholas, 2009; Sierens \& Avermaet, 2017). Even in countries where multilingualism is the norm in education, there have been reports of hierarchical orders among the languages used in multilingual systems that have led to linguistic inequality in favor of the dominant language(s) over the language(s) of the minority groups (e.g., Mohanty, 2010). Most educational language policy research focusing on linguistic (in)equality has looked at this issue in teacher-student and/or student-student communication (see UNESCO, 2003; Hornberger, 2009; Bonacina, 2011; Gorter \& Cenoz, 2016; inter alia). One can understand why the focus has been on students, who are the most vulnerable in such educational systems. However, more attention needs to be drawn to the impact of monolingual policies on communication among teachers within a given constitution. Certainly, such policies can be a source of linguistic inequality and divide among teachers. Unlike teacher-student or student-student multilingual communication, language incompetency is often not a barrier in communication among teachers in the same institution. Indeed, higher education institutions are less likely to recruit staff members who are not competent in the language of instruction/communication in the department they are employed in. However, bilingual teachers might have diverse perceptions of mono-/multilingual language policies that reflect on their language choice when communicating with their colleagues. In EFL contexts, these linguistic preferences can affect teachers' performance in official/unofficial meetings within the institution and can even lead to biases among staff members.

Hence, there are three main questions that the current study tried to address. First, do staff members (i.e., teachers) in Saudi Arabian higher education English departments have freedom in language selection and use (i.e., between English and Arabic) in official meetings? Second, does having English language policies (ELPs) have an impact on teachers' participation in meetings and discussions if they prefer to communicate in Arabic? 
Finally, how do staff members perceive other staff members who do not use English in departmental communications? To answer these questions, a questionnaire was distributed to more than 200 staff members in Saudi Arabian English departments in higher education institutions, and semi-structured interviews were conducted with the chairpersons of these departments. Data were obtained from both genders and from staff members majoring in various areas of specialty. The participants also belonged to various age groups. More than half the participants in the questionnaire survey either believed that they did not have the right or were unsure whether they had the right to use either Arabic or English in official meetings. Participants, however showed awareness of the importance of using language policies to secure the rights of non-Arabic speaking staff members. Strictly monolingual language policies were reported by questionnaire respondents and interviewees as potential obstacles that hinder less competent members from actively participating in committee meetings and department council discussions.

\section{Literature Review}

The field of language planning and policy (LPP) is by nature abundant in conflicting views among researchers. This could be the reason that field LPP seems to lack a "grand theory" (Jonson, 2013, p. 26). These divergent opinions surrounding LPP result from historical, political, economic, humanistic, and educational factors that are perhaps beyond the scope of the current study. Nevertheless, it is essential to take these divergent opinions into consideration when defining the meaning of the term language policy in this study.

\subsection{Defining Language Policy}

Indeed, some strict definitions of LPP (such as Kaplan \& Baldauf, 1997) do not account for micro-level language policies (i.e., those created by speech communities rather than politicians and other authoritative bodies). Other definitions include the beliefs and practices of communities with regard to language use, choice, and acquisition (see Schiffman, 1996; Spolsky, 2004; Johnson, 2013). The inclusion of unofficial policies as well as beliefs and practices of communities in the definition of language policies is undoubtedly legitimate because communities can create or implement language policies on their own without any governmental intervention. Proponents of stricter definitions of language policies, though, might criticize this view because many aspects of our daily language use, such as clearing one's throat to warn a student of a linguistic mistake he or she has made, can be regarded as language policies. One potential solution to this predicament of defining LPP is to have a definition that acknowledges LPPs in both their strict and broad senses. Traditional definitions of language policies, which view them as official, overt, and top-down, are a part of language policies in the strict sense because they are agreed upon as language policies by all researchers in the field. Debatable beliefs and practices can thus be defined as policies, but in the broad sense of the term "LPPs". Hence, the practices and beliefs of staff members in Saudi Arabian English departments in higher education institutions regarding language use and language choice are referred to as language policies in the current study, regardless of the type of language policy (i.e., whether they are officially documented or not or whether these departmental policies are overtly expressed or covertly agreed upon among staff members).

\subsection{The Status of English in Saudi Arabia}

Although official Saudi documents have an explicit language policy in which Arabic is recognized as the official language of the country (see The Saudi constitution Chapter 1, Article 1), there seems to be an implicit policy in which English is bestowed a high status in terms of both acquisition planning and status planning (Alnasser, 2018). Regarding the first type of planning, English is the only foreign language taught in the Saudi general education system (see Alasmari \& Khan, 2014; Alkhuzay, 2015). English is also an essential part of higher education in Saudi Arabia. In almost every Saudi university, there are English departments in which students can specialize in English literature, translation, or linguistics. Students of other specialties are also required to take English for specific purposes courses. Acquisition planning of English is supported by officials as well as by public positive attitudes towards English as a lingua franca and as an indicator of being well qualified for the job market. Acquisition planning and status planning seem to intertwine here because the high status of English makes it worth teaching to Saudi students. Likewise, the need for English competency in the job market necessitates teaching it to students. The implicit ELP in Saudi Arabia is also evident in other aspects besides education. For example, English is present in the Saudi linguistic landscape, where bilingual street signs, shop names, and building names are the norm, and in the media, where TV stations, radio channels, and newspapers communicate news in English (see Rao, 2007).

\subsection{Language Policy and Power}

The discussion of the definitions of language policies above touched on the issue of LPPs and power, which is of vital importance given the focus of this research study. The language policies investigated in the current study 
are created, interpreted, and implemented by groups with various degrees of power (chairpersons, department council members, teaching staff members, and students).

Many researchers such as Tollefson (1991), Phillipson (2003), Shohami (2006), and McCarty (2011) advocate a critical language policy framework in which LPP is viewed as a mechanism of power that is used by the more powerful groups within a society to reinforce their dominance over minority language groups. In other words, the researchers accuse language policies of acting like a barrier between minority groups and access to political power and economic assets. Although this is true in many cases, LPPs have also been used to guarantee the rights of minority groups or to protect endangered languages. Hence, Kloss (1998) and Wiley (2002) argue that there should be a distinction between the array of language policies, from the ones most open-minded towards minority groups (promotion-oriented language policies) to the ones most oppressive of minority groups (repression-oriented language policies). An example of a promotion-oriented language policy is the promotion of minority language rights in the educational systems of Kazakhstan and Kyrgyzstan (Stoianova \& Angermann, 2018). It appears that the works of critical language policy proponents, as well as administrative support for the linguistic rights of minority groups (e.g., The Organisation for Security and Cooperation in Europe; see Ulasiuk, Hadirca, \& Romans, 2018), have led to global recognition of the rights of minority groups. However, as argued by Johnson (2012) in his study of language policy and power in US schools, language policies created at the school level are put forward by dominant groups' "arbiters", whereas the rest of members in the educational system are just "implementers" of the policy. Hence, even in linguistic communities where minority language groups are supported, there can be an imbalance of powers regarding language policy creation and interpretation of language policy texts. Indeed, if the interpretation of official, top-down, policy texts is left to powerful individuals in a linguistic community, then we face another form of marginalization of minority groups. In a recent study on the beliefs of staff members in Saudi Arabian higher education about ELPs, 36\% of the studied sample suggested that the department is the authority that should be in charge of language policy creation, whereas only $4.3 \%$ proposed that ELPs should be created by the Ministry of Education. The rest of the respondents advocated the collaboration of multiple layers in language policy creation (the ministry, the university, and the department; Alnasser, 2018). None of the staff members in Alnasser's study suggested that students be involved in language policy creation. This is an indication of staff members' lack of acknowledgement of the right of students to engage in the creation or elaboration (i.e., revision) of existing language policies.

An essential issue in the investigation of language policy and power is multilingual members' ability to freely choose between the languages in their linguistic repertoires in official settings. Hence, one of the questions that the current study tries to answer is whether individuals in English departments think they have the freedom to choose between Arabic and English in their departments' official meetings.

\section{Data and Methodology}

The main purpose of the current study was to investigate language policies as mechanisms of power in higher education English departments in Saudi Arabia. The study also investigated the impact of having monolingual ELPs on the engagement of staff members in official meetings and discussions. Ideally, this requires careful observation of the practices of staff members and chairpersons in official departmental and committee meetings. However, such meetings are inaccessible to outsiders. Hence, a questionnaire was distributed to teaching staff, and interviews were conducted with a sample of chairpersons in these departments. Additionally, being an insider in these institutions and working at three English departments in Saudi Arabia over the last thirteen years also helped in reporting and commenting on ELPs in Saudi English departments. Both the questionnaire and interviews were designed to serve the purpose of answering the following research questions:

- Do bilingual staff members (in Arabic and English) freely choose which language to use in official meetings in their departments?

- What is the impact of monolingual ELPs on the participation of staff members in official meetings?

- What perception do staff members have of their colleagues who do not use English in department meetings?

Two hundred and eight staff members responded to the questionnaire. The respondents were men and women from various areas of specialty, age groups, academic ranks, and geographical regions. This wide range of responses from various groups contributed to the collection of data from different arbiters and recipients of language policies in Saudi English departments. The questionnaire respondents' details are provided in Table 1. 
Table 1. Questionnaire respondents' background information

\begin{tabular}{|c|c|c|c|c|}
\hline Group & Classification (no. of resp & idents) & & \\
\hline Gender & Female (143) & & Male (65) & \\
\hline Academic rank & Language instructor (68) & Lecturer (92) & Assistant professor (36) & Other (12) \\
\hline Age group & $25-35(70)$ & $36-45(99)$ & $46-55(29)$ & Other (11) \\
\hline Location of institution & South (88) & Centre (65) & North (28) & Other (27) \\
\hline Nationality & Saudi (71) & Indian $(62)$ & Sundanese (16) & Other (59) \\
\hline Specialty & Literature (84) & Linguistics (80) & Translation (9) & Other (35) \\
\hline
\end{tabular}

After providing their background information, respondents were asked to rate their regularity of English use in their departments' official meetings on a quintuple scale ranging from always on one end to never on the other. The respondents were asked about seven occasions where linguistic communication takes place: council meetings, committee meetings, e-mail communication, announcements when communicating with students, side discussions with other staff members during work hours, nonacademic meetings and discussions, and provision of verbal instructions to other members. The purpose of asking respondents about which language is typically used on such occasions is that mere language selection and use is viewed as a language policy; see Spolksy (2004).

To analyze the impact of ELPs on staff members' engagement in official meetings at the department level and to investigate how power manifested in their language policy preferences, respondents were asked about their perceptions of ELPs and to indicate how strongly they agreed or disagreed with these three statements: I have the right to use either language (Arabic or English) during any council/committee meeting, English must be used when a non-Arabic speaking member of staff is present, and Members of staff who choose not to use English tend to refrain from participating in discussions. The first statement investigated whether the responding staff members believed that selecting their language of communication was an option. Answers to this question can not only provide insight into teachers' beliefs, which are an essential part of language policies (see Johnson, 2013), but also inform us about the power that respondents have in the selection of one of the languages in their linguistic repertoire. The second statement explored staff members' attitudes and consciousness towards linguistic equality because using Arabic in the presence of non-Arabic speakers excludes those members from participation in official meetings (see Tollefson, 2013; de Oliveira, 2017; Goemans, 2018; inter alia for discussion on language policy and minority groups rights). The third statement revealed the potential impact of adopting a monolingual ELP on the participation of staff members in official discussions. To understand respondents' perceptions of other staff members who did not adopt a monolingual ELP, they were asked the following question:

- Not using English at departmental encounters can be an indicator of

(a) An individual's negative attitude towards English

(b) An individual's preference for the use of Arabic

(c) Other

The beliefs and practices of chairpersons are of vital importance to the issue of language policy and power in the institutions under investigation. Indeed, chairing department councils give department chairpersons more power in language policy creation, interpretation, and appropriation. Hence, interviews were conducted with eight department chairpersons from five Saudi universities to study their implementation of language policies and to examine the potential impact of monolingual language policies on English department members. Informants were asked the following questions:

- Do you implement a monolingual language policy in your department?

- What is the impact of your current language policy on the members of your department?

The following section discusses the results of the questionnaire survey and the interviews.

\section{Results and Discussion}

As detailed above, the tools used for data collection were an online questionnaire and interviews with department chairpersons. The questionnaire was designed to answer two main questions. The first question concerned the ELPs implemented as a part of Saudi English departments' language policy and the second question dealt with the potential impact of departmental language policies on department members. Table 2 lists the responses to the first question. 
Table 2. The frequency of English use in various departmental interactions outside the classroom domain

\begin{tabular}{|c|c|c|c|c|c|}
\hline \multicolumn{6}{|c|}{ How often do you use English on the following occasions? } \\
\hline Frequency & Always & Often & Sometimes & Rarely & Never \\
\hline \multicolumn{6}{|l|}{ Occasion } \\
\hline Council meetings & $140(67.3 \%)$ & $37(17.7 \%)$ & $19(9.1 \%)$ & $8(3.8 \%)$ & $4(1.9 \%)$ \\
\hline Committee meetings & $139(66.8 \%)$ & $37(17.7 \%)$ & $16(7.6 \%)$ & $10(4.8 \%)$ & $6(2.8 \%)$ \\
\hline E-mail correspondence with colleagues & $169(81.2 \%)$ & $19(9.1 \%)$ & $9(4.3 \%)$ & $8(3.8 \%)$ & $3(1.4 \%)$ \\
\hline Announcements & $122(58.6 \%)$ & $50(24 \%)$ & $21(10 \%)$ & $10(4.8 \%)$ & $5(2.4 \%)$ \\
\hline With students & $134(64.4 \%)$ & $56(26.9 \%)$ & $13(6.2 \%)$ & $5(2.4 \%)$ & $0(0 \%)$ \\
\hline During work hours & $97(46.6 \%)$ & $73(35 \%)$ & $25(12 \%)$ & $12(5.7 \%)$ & $1(0.4 \%)$ \\
\hline Nonacademic meetings with colleagues & $69(33.1 \%)$ & $66(31.7 \%)$ & $46(22.1 \%)$ & $18(8.6 \%)$ & $9(4.3 \%)$ \\
\hline Verbal instructions to colleagues & $137(65.8 \%)$ & $34(16.3 \%)$ & $19(9.1 \%)$ & $11(5.2 \%)$ & $7(3.3 \%)$ \\
\hline
\end{tabular}

Responses to the frequency of English use in various forms of interaction outside the domain of the classroom revealed that English is predominantly used in all of the occasions under investigation. This became clear when comparing the figures in the always and often columns with those in the rarely and never columns. This is an expected finding given that the data were obtained from English department members. What is interesting, though, is the attested variation in the frequency of English use across different forms of interaction and various degrees of formality. For instance, approximately $66 \%$ of the respondents reported that English is always used with students, when giving instructions to colleagues, and in department council and committee meetings. This was twice as many as the number of respondents who reported that English is always used in personal, nonacademic communication with colleagues (33\%). These figures can also be compared to the adoption of monolingual ELPs during work hours (46\%), where interactions can sometimes be informal. The percentage of strictly monolingual ELPs is even higher in e-mail correspondence (81\%). E-mail communication is of a higher formality, and the issues discussed via e-mail mostly relate to work. It is possible that the nature of e-mail communication, which involves writing rather than verbal communication, has also contributed to this higher percentage of persistent English use. Announcements are slightly lower than other formal domains because they are directed at students and visitors to English departments, who are not necessarily competent in English.

Although Table 2 revealed that there is a very small number of staff members who rarely or never use English in various forms of interaction outside the classroom domain, it is still worth examining the impact of monolingual ELPs on those members and investigating how other staff members perceive them. Another issue that is related to language policy and power is whether respondents think that they have the right to use whichever language they are competent with. In other words, do staff members perceive themselves as policy creators or policy implementers? The next set of questions in the questionnaire tackles these issues. The respondents were given four statements and were instructed to choose the extent to which they agreed or disagreed with them. Table 3 lists the statements and the responses to them.

Table 3. Staff members' perceptions of language policies

\begin{tabular}{|c|c|c|c|c|c|}
\hline \multicolumn{6}{|c|}{ To what extent do you agree/disagree with the following statements? } \\
\hline $\begin{array}{l}\text { Opinion } \\
\text { Statement }\end{array}$ & $\begin{array}{l}\text { Strongly } \\
\text { agree }\end{array}$ & Agree & Not sure & Disagree & $\begin{array}{l}\text { Strongly } \\
\text { disagree }\end{array}$ \\
\hline $\begin{array}{l}\text { I have the right to use either language (Arabic or English) } \\
\text { during any council/committee meeting. }\end{array}$ & $27(12.9 \%)$ & $67(32.2 \%)$ & $32(15.3 \%)$ & $52(25 \%)$ & $30(14.4 \%)$ \\
\hline $\begin{array}{l}\text { English must be used when a non-Arabic speaking member } \\
\text { of staff is present. }\end{array}$ & $146(70.1 \%)$ & $39(18.7 \%)$ & $6(2.8 \%)$ & $10(4.8 \%)$ & $7(3.3 \%)$ \\
\hline $\begin{array}{l}\text { Although official documents discussed in department } \\
\text { councils are written and will be officially responded to in } \\
\text { Arabic, they should be discussed in English. }\end{array}$ & $120(57.6 \%)$ & $51(24.5 \%)$ & $19(9.1 \%)$ & $11(5.2 \%)$ & $7(3.3 \%)$ \\
\hline $\begin{array}{l}\text { At council/committee meetings, members of staff who } \\
\text { choose not to use English tend to refrain from participating } \\
\text { in discussions. }\end{array}$ & $37(17.7 \%)$ & $54(25.9 \%)$ & $75(36 \%)$ & $30(14.4 \%)$ & $12(5.7 \%)$ \\
\hline
\end{tabular}

The respondents' answers to the first statement suggest that staff members seem to have conflicting views on whether they have the power to be language policy creators in out-of-class encounters. Nearly $45 \%$ of the sample agreed with the statement that they "have the right" to use either English or Arabic in department meetings. The $40 \%$ who disagreed with this statement appeared to think of themselves as mere implementers of language 
policies set by their departments. The rest of the respondents $(15 \%)$ were not certain about their role in the creation or implementation of language policies. The vast majority of respondents (nearly $89 \%$ ) agreed with the statement about avoiding the use of Arabic in out-of-classroom encounters if non-Arabic speaking colleagues are present. It is clear that staff members are aware that multilingual language policies can create linguistic hierarchies and communication gaps in the presence of non-Arabic speakers.

Answers to the third statement indicated that the majority of respondents $(82 \%)$ believe their departments have the power to use a language that is different from the official language of their constitution. The rest of the respondents did not necessarily believe in the opposite (i.e., that their department should not use a language for communication other than that used by the institution). Some respondents may have decided to disagree with this statement because they thought that translating documents is time-consuming. This high percentage of agreement with the statement also shows that the majority of English department staff members supported having monolingual ELPs. This support for ELPs in out-of-classroom communication may have negative consequences, especially for those who do not use English to communicate. The fourth statement assessed the potential impact of implementing monolingual ELPs on staff members. A considerably large number of respondents (44\%) consider ELPs to be an obstacle that leads some members to refrain from participating in departmental discussions in English. A large portion of the sample (35\%) was not sure about the impact of ELPs on the amount of participation in council discussions. This can be explained by the fact that lack of participation can be caused by plenty of other reasons, such as personality traits, irrelevance of the discussed issue to one's interests, or overall lack of interest in participation.

The respondents were also asked about possible indicators for not using English in department meetings. Because there were many possible indicators, participants could write the possible reason(s) for not using English in department meetings or choose from two possible items: (1) an individual's negative attitudes towards English and (2) an individual's preference for the use of Arabic. According to the majority of the sampled staff members $(75 \%)$, the most likely reason for not using English in departmental communication was one's preference for the use of Arabic for communication. A relatively small portion of the sample (15\%) reported that the possible reason was negative attitudes towards English. Although this seems to be a small percentage, it is a noticeable indicator of negative attitudes towards those who prefer not to communicate in English. Negative views about non-English users can be seen in more radical responses questioning such users' competence in English (5.2\% of the sample). One respondent even reported that the possible reason for not using English is a lack of confidence. Negative views added up to more than $20 \%$ of the sample. Even though this does not constitute a majority, this figure cannot be ignored because it suggests that one-fifth of staff members do not perceive their colleagues who prefer not to communicate in English as qualified for their jobs.

The perceptions of department chairmen on the impact of mono/multilingual policies on department members are important. Indeed, they communicate regularly with all staff members. They are not only present at all council meetings, but they are in charge of initiating discussions and managing all the dialogues of the council. More importantly, they are required by the Saudi Ministry of Labor to evaluate the performance of each staff member by the end of each year. A substantial part of the evaluation is dedicated to staff members' participation in the department council, committee meetings, and other roles and responsibilities. These factors put the department chairmen in a very good position to assess the potential impact of language policies on the performance of staff members. Hence, eight department chairpersons were interviewed to enquire whether there was a positive or negative impact of their department's implemented language policies on the engagement of staff members in discussions in department council and committee meetings. Seven interviewees were men, and one interviewee was a chairwoman. The interviewees, who came from various Saudi provinces, are affiliated with five of the largest Saudi universities. They reported a number of positive and negative effects of implementing monolingual or multilingual language policies. The advantages of monolingual/multilingual policies as well as challenges for implementing ELPs are summarized below.

The interviewed sample revealed different language policy practices across different departments in Saudi institutions. This can also be predicted based on the data in Table 2 above. These variations are indeed helpful when trying to discover the merits and demerits of implementing monolingual ELPs in out-of-classroom communication. Departments that implement monolingual ELPs in their official meetings reported a number of advantages and disadvantages, but we are mostly concerned here with the impact of these policies on staff members both in terms of participating in discussions and the inclusion/exclusion of non-Arabic speakers.

Three interviewees stressed that a monolingual ELP provides the benefit of more exposure to English. Using English to communicate with proficient colleagues improves the competency levels of staff members. One interviewee even suggested that strictly monolingual ELPs lead to more English use when communicating with 
students in the classroom. Further, the female interviewee suggested that it is actually easier for her and her colleagues to communicate in English because they are used to it, although they all speak Arabic as their first language. Another chairperson reported that there is a large number of non-Arabic speakers in their department. Hence, they do their best to avoid the use of Arabic in official meetings. Otherwise, those members will have the impression that they are marginal members of the department council. Interestingly, the latter interviewee reported that they even translate side jokes that are told in Arabic during meetings to non-Arabic speaking members. This is indeed a fascinating language policy practice because it takes into consideration the rights of non-Arabic speakers to fully participate in official meetings. The interviewed department chairpersons also reported a number of challenges for implementing ELPs, with the most reported challenge being the lack of participation by incompetent and low-esteemed members. Some of these members, according to one of the interviewees, prefer to remain silent in official meetings to avoid the embarrassment of making grammatical or pronunciation mistakes. Others might even find it difficult to express themselves in English on some occasions, according to one of the interviewed chairpersons. Additionally, according to one of the interviewed chairpersons, multilingual language policies provide the benefit of easier communication between Arabic speakers. Multilingual language policies can also make discussing some administrative terms that are difficult to translate into English much easier for staff members.

The overall results of both the questionnaire surveys and the interviews suggest that the advantages of implementing monolingual ELPs in out-of-classroom EFL contexts outweigh the disadvantages, especially in the presence of speakers who are not familiar with the local language. More exposure to and practice of English by nonnative speakers of English department members would certainly improve the overall competence of members in English, leading to a better teaching experience for students in these departments. The results also indicate that the majority of the sampled respondents and interviewees use language policies in a positive way when it comes to the inclusion of non-Arabic speakers. More effort needs to be made, however, to reduce negative impressions about incompetent members and about other staff members who do not use English in official meetings.

\section{Conclusion}

The current study attempted to discover the impact of language policies on English department members in Saudi Arabia from a language and power perspective. The analyzed data suggest that monolingual ELPs can help staff members continue practicing English outside the domain of the classroom with competent speakers of English. There are challenges to implementing monolingual ELPs, however, such as dealing with Arabic documents circulated within the institution and less participation and engagement in department councils' dialogues and committee discussions by less competent members. Further, monolingual ELPs can lead to tensions between staff members, where less participation in English or even the mere use of Arabic in official meetings can be interpreted by some members as a sign of incompetence and consequently a lack of eligibility for the job of English teaching. At the same time, adopting multilingual language policies, where both English and Arabic are used in official meetings, marginalizes non-Arabic speakers.

There are a number of implications of these results for English departments in Saudi Arabia, as well as similar institutions worldwide. Although it was difficult to verify the claims of both the questionnaire survey participants and interviewees that lack of participation can be the result of lack of competence in English, these claims call for careful measures for recruiting staff members. Multilingual language policies can be useful, but they are hardly applicable, given that in many cases, English is the only common language among all department members. The absence of clear roles for department members as policy implementers or policy arbiters calls for clearer regulations for the creation and appropriation of language policies. Finally, department chairpersons are advised to assure their department members that foreign accents are common among nonnative speakers of a language. The preference for remaining silent to avoid mispronouncing some words or making a slight grammatical mistake is a major challenge facing EFL educational institutions that hire nonnative English speakers. This challenge is difficult to overcome without more tolerant language policies for nonnative speakers and world Englishes.

Future research on out-of-classroom language policies in EFL contexts can be conducted on gender-based differences among staff members. Unlike all other interviewees participating in the current study, the female chairperson we interviewed suggested that it was easier for her and for her Arabic-speaking colleagues to communicate in English. If this is a common practice among female department members, then the impact of implementing monolingual ELPs can be conditioned by gender. Unfortunately, it was difficult for the current study to verify this by collecting more data from female chairpersons because of cultural reasons. The impact of adopting monolingual ELPs among department staff members on the teaching experience of such members can also be investigated in future research. 


\section{Acknowledgements}

The author would like to thank the Deanship of Scientific Research and RSSU at King Saud University for their technical support.

\section{References}

Alkhuzay, S. (2015). Introducing English as a second language to early primary school curriculum in Saudi Arabia. Arab World English Journal, 6(2), 365-371. https://doi.org/10.24093/awej/vol6no2.28

Alnasser, S. (2018). Investigating English language policies in Saudi higher education English departments: Staff members' beliefs. Linguistics and Literature Studies, 6(4), 11.

Bonacina, F. (2011). A conversation analytic approach to practiced language policies: The example of an induction classroom for newly-arrived immigrant children in France. Retrieved from http://hdl.handle.net/1842/5268

de Oliveira, G. M., \& da Silva, J. I. (2017). When language barriers engender human rights violations: Which language policies is the Brazilian State adopting in order to guarantee access to basic public services for immigrants? Gragoata-Uff, 22(42), 131-153. https://doi.org/10.22409/gragoata.2017n42a909

Goemans, P. (2018). Group rights, participatory goods, and language policy. University of Toronto Law Journal, 68(2), 259-292. https://doi.org/10.3138/utlj.2017-0021

Gorter, D., \& Cenoz, J. (2017). Language education policy and multilingual assessment. Language and Education, 31(3), 231-248. https://doi.org/10.1080/09500782.2016.1261892

Johnson, D. C. (2012). Positioning the language policy arbiter: Governmentality and footing in the School District of Philadelphia. In. J. W. Tollefson (Ed.), Language policies in education: Critical issues. London and New York: Routledge.

Johnson, D. C. (2013). Language policy. New York: Palgrave Macmillan. https://doi.org/10.1057/9781137316202

Kaplan, R. B., \& Baldauf, R. B. (1997). Language planning from practice to theory. Clevedon: Multilingual Matters.

Kloss, H. (1998). The American bilingual tradition. Rowley, Mass.: Newbury House.

McCarty, T. L. (2011). Introducing ethnography and language policy. In T. L. McCarty (Ed.), Ethnography and language policy (pp. 1-28). London: Routledge.

Mohanty, A. (2010). Languages, inequality and marginalization: Implications of the double divide in Indian multilingualism. International Journal of the Sociology of Language, 205, 131-154. https://doi.org/10.1515/ijsl.2010.042

Nicholas, A. B. (2009). Linguistic decline and the educational gap: A single solution is possible in the education of indigenous peoples. from https://www.ohchr.org/Documents/Issues/IPeoples/EMRIP/StudyLanguages/AssemblyFirstNations7.pdf

Phillipson, R. (2003). English-only Europe? Challenging language policy. London: Routledge.

Rao, S. (2007). The media globe: Trends in international mass media. Journalism \& Mass Communication Quarterly, 84(4), 858-860.

Schiffman, H. F. (1996). Linguistic culture and language policy. London: Routledge. https://doi.org/10.4324/9780203273487

Shohamy, E. G. (2006). Language policy: Hidden agendas and new approaches. London: Routledge. https://doi.org/10.4324/9780203387962

Sierens S., \& Van Avermaet, P. (2017). Bilingual education in migrant languages in Western Europe. In O. García, A. Lin \& S. May (Eds.), Bilingual and multilingual education. Encyclopaedia of language and education (3rd ed.). Cham: Springer. https://doi.org/10.1007/978-3-319-02258-1_25

Skutnabb-Kangas, T. (2000). Linguistic genocide in education-Or worldwide diversity and human rights? Mahwah, NJ, and London: Lawrence Erlbaum Associates, Publishers.

Spolsky, B. (2004). Language policy. Cambridge: Cambridge University Press. 
Stoianova, A., \& Angermann, M. (2018). The HCNM impact on minority and state language promotion and on the social integration of diverse societies through education: The cases of Kazakhstan and Kyrgyzstan. In I. Ulasiuk, L. Hadirca \& W. Romans (Eds.), Language policy and conflict prevention. Leiden, the Netherlands: Brill Nijhoff. https://doi.org/10.1163/9789004357754_008

Tollefson, J. W. (1991). Planning language, planning inequality: Language policy in the community. London: Longman.

Tollefson, J. W. (2013). Language policies in education critical issues (pp. xi, 316). Retrieved from http://www.ezproxy.is.ed.ac.uk/login?url=http://www.tandfebooks.com/isbn/9780203813119

Ulasiuk, I., Hadirca, L., \& Romans, W. (Eds.). (2018). Language policy and conflict prevention. https://doi.org/10.1163/9789004357754

UNESCO. (2003). Education in a multilingual world (UNESCO education position paper). Retrieved from http://unesdoc.unesco.org/images/0012/001297/129728e.pdf

Wiley, T. (2002). Accessing language rights in education: A brief history on the U.S. context. In J. W. Tollefson (Ed.). Language policies in education: Critical issues. Mahwah, NJ: Lawrence Erlbaum Associates, Inc.

\section{Copyrights}

Copyright for this article is retained by the author, with first publication rights granted to the journal.

This is an open-access article distributed under the terms and conditions of the Creative Commons Attribution license (http://creativecommons.org/licenses/by/4.0/). 